\title{
BUDAYA ORGANISASI PADA DINAS PENANAMAN MODAL DAN PELAYANAN TERPADU SATU PINTU PROVINSI RIAU
}

\author{
Fara Merian Sari \\ Universitas Lancang Kuning Dumai \\ e-mail: farafia@unilak.ac.id
}

\begin{abstract}
Organizational Culture is a shared value system in an organization that is a reference for how employees carry out activities to achieve the goals or goals of the organization. This is stated as the vision, mission and goals of the organization. Organizational culture is developed from a collection of norms, values, beliefs, hopes, assumptions, and philosophies of the people in it. The purpose of this research is to find out and analyze the Organizational Culture of the One-Stop Integrated Investment and Services Office of Riau Province and to analyze the obstacles in the Organizational Culture of the Department of Investment and One-Stop Integrated Services of the Riau Province. In this study the authors use the concept of theory according to Jerald Greenberg and Robert A. Baron (2010: 36) suggesting that there are seven elements that show the characteristics of organizational culture, among others, innovation, stability, orientation to people, orientation to results, being calm, attention to details, orientation to collaboration.
\end{abstract}

Keywords:Organizational Culture, Service, Employess

\begin{abstract}
Abstrak
Budaya Organisasi merupakan system nilai bersama dalam suatu organisasi yang menjadi acuan bagaimana para pegawai melakuakan kegiatan untuk mencapai tujuan atau cita cita organisasi. Hal ini dinyatakan sebagai visi, misi dan tujuan organisasi. Budaya organisasi dikembangkan dari kumpulan norna-norma, nilai, keyakinan, harapan, asumsi, dan filsafat dari orang-orang didalamnya. Tujuan dari penelitian ini adalah untuk mengetahui dan menganalisis Budaya Organisasi Pada Dinas Penanamam Modal dan Pelayanan Terpadu Satu Pintu Provinsi Riau dan untuk menganalisis hambatan- hambatan dalam Budaya Organisasi pasa Dinas Penanama Modal dan Pelayanan Terpadu Satu Pintu Provinsi Riau. Dalam penelitian ini penulis menggunakan konsep Teori menurut Menurut Jerald greenberg dan Robert A. Baron (2010:36) mengemukakan bahwa terdapat tujuh elemen yang menunjukan karakteristik budaya organisasi antara lain sebagai berikut, inovasi, stabilitas, orientasi pada orang, orientasi pada hasil, bersikap tenang, perhatian pada hal detail, orientasi pada kolaborasi.
\end{abstract}

Kata Kunci : Budaya Organisasi, Pelayanan, Pegawai

\section{PENDAHULUAN}

Budaya Organisasi merupakan system nilai bersama dalam suatu organisasi yang menjadi acuan bagaimana para pegawai melakuakan kegiatan untuk mencapai tujuan atau cita cita organisasi. Hal ini dinyatakan sebagai visi, misi dan tujuan organisasi. Budaya organisasi dikembangkan dari kumpulan norna-norma, nilai, keyakinan, harapan, asumsi, dan filsafat dari orang-orang didalamnya.

Organisasi yang baik, tumbuh dan berkembang akan menitik beratkan pada sumber daya manusia (human resources) guna menjalankan fungsinya dengan optimal, khususnya menghadapai dinamika 
perubahan lingkungan yang terjadi . Dengan demikian kemampuan terknis, teoritis, konseptual, moral dari para pelaku organiasi di semua tingkat (Level) pekerjaan amat dibutuhkan.

Pemahaman terhadap budaya organisasi berhubungan erat dengan diversitas dan karakteristik dari orientasi kerja para anggota organisasi. Hal ini akan memberikan gambaran tentang tindakan, reaksi maupun keputusan mereka terhadap situasi pekerjaany masing-masing. Ketika organisasi mulai berorientasi pada pembentukan budaya organisasi, berarti pula meletakaan aspek sumber daya manusia dalam posisi strategis melalui para pimpinan atau menajer untuk megamankan norma perilaku, nilai-nilai dan keyakinan bersamam terhadap organiasi

Provinsi Riau memiliki 25 Dinas, 8 Badan, 12 Kabupeten atau Kota, 166 Kecamatan dan 1846 Kelurahan salah satu dinas nya adalah Dinas Penanaman Modal dan Pelayanan Terpadu Satu Pintu Provinsi Riau yang memiliki 86 pegawai.

Berdirinya Dinas Penanaman Modal dan Pelayanan Terpadu Satu Pintu Provinsi Riau Merupakan Penyelenggarn pelayanan satu pintu (one stop service) untuk melakasanakan sebagian urusan pemerintahan daerah Kota Pekanbaru dalam bidang Pelayanan perizinan dan nonperizinan secara terpadu serta menanamkan modal prinsip koordinasi, integrasi, singkronisasi, simplikasi, keamanan dan kepastian.

Administrasi pelayanan publik Dinas Penananam Modal dan Pelayanan Terpadu satu Pintu Provinsi Riau sesuai kewenangan dan tugas, dituntut untuk mampu memenuhi standar pelayanan publik yang berkelanjutan dan tuntutan reformasi yang berkembang pada masyarakat. Disamping itu administrasi pelayanan diharapkan mampu mengatasi permasalahan yang dihadapi untuk mewujudkan administrasi pelayanan sesuai dengan sasaran dan tujuan organisasi. Artinya, bahwa administrasi pelayanan publik memainkan peranan yang penting didalam menentukan sistem pelayanan publik yang dijalankan Dinas Penanaman Modal dan Pelayanan Terpadu Satu Pintu Provinsi Riau yang efektif.

Dinas Penanaman Modal dan Pelayanan Terpadu Satu Pintu Provinsi Riau terbentuk berdasarkan Peraturan Daerah Nomor 8 Tahun 2008 yang dirubah menjadi Peraturan Daerah Nomor 3 Tahun 2014 tentang Organisasi dan tata kerja Inspektorat, Bappeda dan Lembaga Teknis Daerah di Provinsi Riau yang Dirubah menjadi Peraturan Daerah Provinsi Riau Nomor 4 tahun 2016 Tentang Pembentukan dan Susunan Perangkat Daerah Provinsi Riau.

Pada tahun 2017 lembaga Badan Pelayanan Perizinan Terpadu (BP2T) telah bergabung dengan Badan Penana-man Modal dan Promosi Daerah (BPMPD) menjadi ikatan dinas yang dinamakan Dinas Penanaman Modal dan Pelayanan Terpadu Satu Pintu (DPM-PTSP). Agar tercapainya tujuan yang lebih efektif dan hasil yang maksimal.

Pelayanan Terpadu rekomendasi dan perizinan merupakan suatu terobosan kebijakan strategis pemerintah Provinsi Riau dalam upaya mengantisipasi keluhan masyarakat dan mengahadapi era globalisasi untuk meningkatkan daya saing serta tertibnya legalitas kegiatan masyarakat.

SOP Dinas Penanamam Modal dan Pelayanan Terpadu satu Pintu Provinsi Riau tercantun dalam surat keputusan Guberbur Riau Nomor: Kpts. 673/VIII/2017 tentang penetapan standar operasional prosedure (SOP) dilingkungan Dinas Penanaman modal dan Pelayanan Terpadu Satu Pintu Provinsi Riau. dan Keputusan Gubernur Riau Nomor : Kpts.672/VIII/2017 tentang nama dan kode standar operasional prosedur (SOP) di dinas Penanaman Modal dan Pelayanan TerpaduSatu Pintu Provinsi Riau.

Dinas Penanamam Modal dan Pelayanan Terpadu Satu Pintu Provinsi Riau memiliki 18 Jenis Pelayanan yang dapat melayanani 135 perizinan dan Non Perizinan.

Berikut ini adalah Realisasi Jenis Pelayanan Perizinanan dan non peizinan Tahun 2018 pada Dinas Penanaman Modal dan Pelayanan Terpadu Satu Pintu Provinsi Riau. 
Tabel. I.1 Jenis Pelayanan Serta Target Realisasi Pelayanan Perizinan di Dinas Penanaman Modal dan PelaTerpadu Satu Pintu Provinsi Riau Tahun 2017-2018

\begin{tabular}{|c|c|c|c|c|c|}
\hline \multirow[t]{2}{*}{ No } & \multirow[t]{2}{*}{ Bidang Pelayanan } & \multicolumn{2}{|c|}{2017} & \multicolumn{2}{|c|}{2018} \\
\hline & & Masuk & Selesai & Masuk & Selesai \\
\hline 1 & Perikanan dan kelautan & 207 & 206 & 63 & 63 \\
\hline 2 & Perternakan & 280 & 270 & 92 & 91 \\
\hline 3 & Perkebunan & 7 & 7 & 12 & 10 \\
\hline 4 & $\begin{array}{l}\text { Pertambangan dan } \\
\text { Energi }\end{array}$ & 5 & 5 & - & - \\
\hline 5 & $\begin{array}{l}\text { Industri dan } \\
\text { Perdagangan }\end{array}$ & 127 & 120 & 36 & 35 \\
\hline 6 & $\begin{array}{l}\text { Tanaman Pangan/ } \\
\text { Holtikultura }\end{array}$ & 390 & 378 & 186 & 170 \\
\hline 7 & Perhubungan & 11 & 9 & 20 & 18 \\
\hline 8 & Pekerjaan Umum & 5 & 5 & 3 & 3 \\
\hline 9 & Tenaga Kerja & 280 & 270 & 92 & 91 \\
\hline 10 & Budaya dan Pariwisata & 7 & 7 & 12 & 10 \\
\hline 11 & Kehurtanan & 10 & 10 & 3 & 3 \\
\hline 12 & Kesbangpol dan Limnas & 8.850 & 8.850 & 6.419 & 6.419 \\
\hline 13 & Penanaman Modal & 10 & 10 & 9 & 9 \\
\hline 12 & Lingkungan Hidup & 5 & 5 & 4 & 4 \\
\hline
\end{tabular}

Sumber Data :Dinas Penanaman Modal dan Pelayanan Terpadu Satu Pintu Provinsi Riau

Dalam Tabel di atas dapat kita simpulkan bahwa target dan realisasi pelayanann yang ada pada Dinaas Penanaman Modal dan Pelayanan Terpau Satu Pintu Provinsi Riau sangat bervariasi tingkat pelayanan yang diberikan dan banyak yang mengalami ketidakselesaian dalam penyelesaian perizinan yang ada sehingga mengakibatkan adanya ketidakpuasan dari masyarakat yang mengurus pelayanan tersebut.. Dinas Penanamam modal dan Pelayanan Terpadu Satu Pintu Provinsi Riau merupakan unsure penunjang tugas tertentu pemerintah Provinsi Riau yang berkewajiban melaksanakan urusan pemerintah daerah bidang pelayanan perizinan dan non perizinan dengan upaya untuk menjalankan dan mengembangkan good govermance dengan menerapkan system pengangaran yang jelas, terukur, dan sesuai dengan kondisi rencana straggis ( Rentra) serta tugas dan Fungsi.

Untuk memwujudkan budaya organisasi yang baik, Dinas Penanaman Modal dan Pelayanan Terpadu Satu Pintu Provinsi Riau telah menciptakan nilai-nilai Profesionalisme kepada seluruh aparatur. Profesionalisme dalam arti terampil menyelesaikan seluruh pekerjaan maupun tanggung jawab yang diberikan hingga tuntas, tapat waktu dan berkualitas serta mampu terukur atau tercatat, sesuai dengan kompetensinya sehingga seluruh kerja maupun keputusan yang telah ditetapkan dan dijalankan dapat terlaksana dengan target waktu (quality control) yang telah ditentukan.

Mengingat pentingnya pemberian pelayanan yang dilakukan untuk masyarakat Dinas Penanaman Modal dan Pelayan Terpadu Satu Pintu Provinsi Riau perlu menerapkan budaya organisasi yang diambil dari nilai-nilai budaya setempat dan tidak bertentangan dengan dengan peraturan perundangan guna menunjang tugas pokok dan fungsi organisasi agar berjalan dengan baik.

Dilihat dari Table berikut adalah absensi Pegawai pada Dinas Penanam Modal dan pelayanan Terpadu Satu Pintu Provinsi Riau 
Table I.2 Data absensi Badan Penanam Modal dan Pelayanan Terpadu Satu Pintu pada tahun 2016-2018

\begin{tabular}{ccccccc}
\hline Tahun & Jumlah & Total & \multicolumn{3}{c}{ Tingkat } & Jumlah \\
& Karyawan & Hari & \multicolumn{3}{c}{ Kehadiran } & Kehadiran \\
\cline { 3 - 5 } & & Kerja & Sakit & Izin & Alfa & \\
\hline 2016 & 63 & 221 & 3 & 3 & 5 & 210 \\
\hline 2017 & 79 & 235 & 5 & 7 & 3 & 220 \\
\hline 2018 & 86 & 240 & 7 & 7 & 9 & 217 \\
\hline
\end{tabular}

Sumber Data :Dinas Penanaman Modal dan Pelayanan Terpadu Satu Pintu Provinsi Riau

Menurut tabel diatas dapat dilihat bahwa disetiap tahun jumlah absensi pegawai di Dinas Penanam Modal dan Pelayanan Terpadu Satu Pintu Provinsi Riau mengalami peningkatan. Hal ini mengindikasikan motivasi kerja pegawai yang ada pada intansi tersebut.

Harapan yang berkaitan dengan Budaya Organisasi di Dinas Penanaman Modal dan Pelayanan Terpadu Satu Pintu Provinsi Riau menjadi suatu alat yang strategis bagi menajemen untuk menwujudkan kinerja yang baik, yang pada akhirnya akan tercipta sikap kerja yang positif sehingga memudahkan untuk tercapainya tujuan organisasi secara baik. dengan demikian budaya organisasi yang baik akan membentuk perilaku tindakan pegawai yang aktif dalam berkerja, bersemangat, memiliki inisiatif, mampu mengambil keputusan yang tepat dan loyal terhadap pekerjaan

Namun kenyataanya banyak pegawai kurang mempunyai motivasi yang tingi sehingga hasil pekerjaan yang dilaksanakannya kurang efektif dan efisien untuk memajukan kepentingan organisasi,dan juga terdapat banyak kurangnya kemantapan system social dan kerja sama antara sesama pegawai maupun dengan organisasi lainya.

\section{METODE}

Metode analisis data yang di gunakan dalam penelitian ini adalah metode Deskriktif kualitatif yang dilakukan terhadap data yang diperoleh melalui wawancara dengan menginterpretasikan data tersebut lalu dianalisa dengan model interaktif..

Teknik yang digunakan untuk pengumpulan data dalam penelitian ini adalah sebagai berikut:

a. Obvervasi

Yaitu melalukan pengamatan langsung terhadap objek penelitian. Observasi yang dilakukan dengan mengamati keadaan yang ada di sekitar lingkungan kerja pada Dinas Penanaman Modal dan Pelayanan Terpadu Satu Pintu Kota Pekanbaru kemudian merekamnya menjadi sebuah data untuk menjadi bahan untuk penelitian.

b. Wawancara

Yaitu melakukan Tanya jawab secara langsung kepada responden yang jadi sampel dalam penelitian ini untuk memperoleh informasi tentang berbagai hal yang berkaitan dengan penelitian. c. Dokumentasi

Yaitu teknik pengumpulan data melalui bahan-bahan tertulis dan dokumentasidokumentasi pendukung yang berhubungan langung dengan objek penelitian meliputi profil organisasi, visi dan misi organisasi, data kepegawaian, tugas pokok dan fungsi organisasi, struktur organisasi dan tinjauan kepustakaan. 


\section{HASIL DAN PEMBAHASAN}

Budaya Organisasi merupakan sistem yang dipercayai dan nilai yang dikembangkan diman hal itu menentukan perilaku dari anggota organisasi untuk bertindak dan memecahkan masalah, membentuk karyawan yang mampu mengadaptasi dengan lingkugan dan mempersatukan angota-angota organasisasi. Untuk itu harus diajarkan kepada anggota termasuk anggota yang baru sebagai suatu cara yang benar dalam mengkaji, berfikir dan merasakan masalah yang dihadapi.

Sebagai salah Satu bentuk tanggung jawab pemerintah kepada masyarakat sudah tentunya suatu pelayanan publik yang diselenggrakan pemerintah harus mencakup seluruh masyarakat yang membutuhkannya, dan yang paling penting lagi adalah bagaimana masyarakat dapat merasakan kepuasan dari layanan yang diberikan kepada mereka. dan itu semua harus dapat diberikan sesuai dengan tugas pokok dan fungsi yang telah ditetapkan.

Dalam mengatasi baik masalah eksternal maupun internal Dinas Penanaman Modal dan Pelayanan Terpadu Satu Pintu Provinsi Riau mendapatkan penyelesaian-penyelseaian yang berhasil. Keberhasilan mengatasi berbagai masalah tersebut merupakan dasar bagi tumbuhnya budaya organisasi khususnya di Dinas Penanaman Modal dan Pelayanan Terpadu Satu Pintu Provinsi Riau.

Pembahasan terkait Pelaksaanaan dalam implementasi dalam penelitian ini juga didasari oleh apa yang dikemukanan oleh Jerald greenberg dan Robert A. Baron (2010:36) mengemukakan bahwa terdapat tujuh elemen yang menunjukan karakteristik budaya organisasi yaitu Inovasi, Stabilitas, Orientasi Pada Orang, Orientasi Pada Hasil, Bersikap Tenang, Perhatian pada hal detail, Orientasi pada Kolaborasi. Inovasi merupakan kemampuan untuk menciptakan peerubahan-perubahan yang berguna untuk perbaikan dan kemajuan organisiasi. Hal ini ditinjau dengan ide ide cemerlang dalam mengatasi permasalahan organisasi.

Pada dinas Penanamam Modal dan Pelayanan Terpadu Satu Pintu Provinsi Riau sudah banyak nya inovasi yang dilakukan untk meningkatkan pelayanan yang diberikan kepada masyarakat.

Berdasarkan Hasil Wawancara dengan ibuk Hj. R.Nurhazanah.SH.M.Si Kepala Bidang Pelayanan Dinas Penanaman Modal dan Pelayanaan terpadu satu pintu Provisni Riau Terdapat 19 Inovasi yang dilakukan oleh Dinas Penanaman Modal dan Pelyanan Terpadu Satu Pintu Provinsi Riau adapun inovasi yang dilakukan oleh Dinas Penanaman Modal dan Pelayanan Terpadu Satu Pintu Provinsi Riau yaitu:

a. Sistem Informasi Pelayanan (SIMPLE), Yaitu pengunaan aplikasi web base dimulai dari penerimaan berkas permohonan, proses, survey, sampai dengan pernerbitan izin/ rekomendasi, sehinga proses perizinan menjadi lebih cepat dan transparan

b. Aplikasi SPISISE, Yaitu permohonan dan proses perizinan dilakuakan secara online

c. Arsip Digital, Merupakan fitur pengarsipan dokumen perizinanan dan nonperizinan secara elektronik (softcopy) dengan proses scan terlebih dahulu, sehingga pencarian dokumen perizinan dan non perizinan menjdai lebih mudah dan penyimpanan dokumen lebih aman

d. Aplikasi E-Vote, Merupakan penilaian kepuasan terhadap pelayanan yang ditampilkan melalui tablet, pemohon dapat menyentuh layat tablet untuk memberikan penilaian "puas" , "cukup", "tidak Puas", untuk pilihan "tidak puas", menampilkan "biaya", "waktu", "petugas", "mekanisme", "sarana" dan menampilkan grafik penilaian perloket secara real time pada layar TV

e. Sistem Antrian Digital, Merupakan aplikasi untuk mempermdah pemohon dalam mengantri pengurusan perizinan, shingga pelayanan menjadi lebih tertip dan lebih andil

f. Perizinan Online, Diakses permohoman melalui media internet http://Perizinan Online.dpmptsp.riau.go.id

g. Pengaduan Online, Diakes melalui media internet dengan alamat web/url http://dpmptsp.riau.go.id 
h. Mobile Perizinan, Yaitu Aplikasi berbasis android di download pada playstore

i. Mobile Pengaduan, Yaitu Aplikasi berbasis android di download pada playstore

j.Barcode PNP (QRCODE), Merupakn sebuah kode (QRCODE) sebagai keamanan ( security) dan identitas terhadap dokumen yang diterbitkan

k. Trackig System PNP, Merupakan layanan yang berfungsi untuk melacak status perizinan dan non perizinan yang diakses melalui media internet

1. E-Database PNP Kab/Kota, Merupakan Integrasi system data perizinan dan nonperizinan yang diterbitkan oleh kabupaten atau kota secara online yang dapat diakses melalui simple

m. Touc Screen PNP, Merupakan aplikasi yang menyajikan dta dan informasi jenis, persyaratan dan waktu penyelesaian perizinan dan non perizinan mengunakan panel layar sentuh (Touc Screen)

n. SMS Gatway, Merupakan layanan yang berfungsi untuk memberikan informasi terkait status perizinan dan nonperizinan

o. LKPM Online, Merupakan Laporan kegiatan penanamam Modal online

p. SKPD Online, Merupakan aplikasi untuk menyampaikan surat pengantar, pertimbangan teknis, bap antaran DPMPTSP dengan instansi teknis ataupun sebaliknya secara online dapat diakses melalui aplikasi simple

q. E- Signature PNP, Merupakan aplikasi tanda tanggan elektronik yang digunakan untuk membuktikan keaslian identitas pengirim dari suatau pesan atau penadatangaan dari suatu dokumen berbasis web

r. Riset Online, Merupakan aplikasi yang terintegritas dengan simple dan mengunakan fitur tte. permohonan dapat mengajukan tampa harus datang ke kantor DPMPTSP. Varifikasi data pemohon melibatkan pihak kampus

s. Klinik LKPM, Merupakan ruang konsultasi untuk menyampaikan pelaporan perkembangan kegiatan penanamam modal bagi perusahaan yang memperoleh IP penanaman modal

Dengan adanya sistem administrasi pelayanan publik DPMPTSP Provinsi Riau secara elektronik dan non elektroik maka dapat menjawab tantangan perubahan lingkungan atau kebutuhan yang bersifat mendadak/mendesak (pengaduan online dan perizinan online). Penggunaan teknologi informasi dalam pelayanan publik dapat dilaksanakan dengan lebih rapi terkendali, sederhana dan mudah dipahami baik oleh masyarakat maupun aparatur pemerintahan. Pelayanan publik terkait dengan, informasi, prosedur pendaftaran dan penerbitan perizinan yang dapat memperpendek rentang administrasi tersebut sebagai keunggulan kompetitf.

\section{Hambatan Budaya Organisasi PAda Dinas Penanaman Modal dan Pelayanan Terpadu Satu Pintu Provinsi Riau}

Budaya organisasi pada dinas Penanaman Modal dan Pelayanan terpadu satu Pintu tidak terlepas dari hambatan- hambatan, setelah penulis melakukan penelitian dan berdasarkan hasil wawancara yang penulis lakuakan ditemui beberapa hambatan dalam budaya organisasi, dimana hambatan tersebut yaitu : Lamanya penerbitan izin yang dilakukan pada Dinas Penanamam Modal dan Pelayanan Terpadu Satu Pintu Provinsi Riau. dapat dilihat dari hasil wawancara :

"kami juga melakukan perubahan system, dan mulai dari pembaharuan persyaratan dalam pengurusan pelayanan hingga yang dulu lamanya pengurusan pelayanan 3 bulan dan sekarang waktu pnyelesaiaan lebih efisien ada yang selesai dalam 14 hari kerja dan ada juga dengan 1 hari pelayanan selesai seperti pengurusan Riset". (Hasil Wawancara dengan ibuk Hj. R.Nurhazanah.SH.M.Si Kepala 


\section{Bidang Pelayanan Dinas Penanaman Modal dan Pelayanaan terpadu satu pintu Provisni Riau, Senin 01 Juli 2019)}

Penulis melihat berdasarkan hasil wawancara dengan Kepala Bidang bahwa dalam melakukan penerbitan Perizinan dan Non Perizinan di Dinas Penanaman Modal dan Pelayanan Terpadu Satu Pintu Provinsi Riau sudah melakukan pembaharuan sisten namum pada kenyataan dilapangan masih adanya tidak terselesaikannya penerbitan izin pelayanan.

Lemahnya pemberian sanksi Pada Dinas Penanamam Modal dan Pelayanan Terpadu Satu Pintu Provinsi Riau. dapat Dilihat dari hasil wawancara

"Hampir setiap hari kami melakukan pelayanan, karna kami ada lah pelayan masyarakat sehingga kami pegawai sangat efektif dalam melakuakan pelayanaan dan apabila kami melangar aturan yang ditentukan kami mendapatkan punishment/ sanksi yitu pemotongan gaji, bagi pegawai yang telat apel pagi atau yang keluar saat jam kerja itu masih ada tapi mereka diberikan sanksi seperti memberikan teguran dan kalau ngak ikut apel akan ada pemotongan gaji Hasil Wawancara Pegawai Dinas Penanaman Modal dan Pelayanaan terpadu satu pintu Provisni Riau, Senin 01 Juli 2019)

Penulis melihat dari hasil wawancara dengan pegawai Dinas Penanaman Modal dan Pelayanan Terpadu Satu Pintu Provinsi Riau masih adanya pegawai Dinas penanaman Modal dan Pelayanan Terpadu Satu Pintu Provinsi Riau yang terlambat atau pun tidak berada dikantor saat jam kerja walapun telah adanya sanksi yang diberikan, akan tetapi faktanya dilapangan masih banyaknya pegawai Dinas Penanaman Modal dan Pelayanan Terpadu Satu Pintu Provinsi Riau yang melanggar peraturan yang telah ditetapkan oleh Dinas Penanaman Modal dan Pelayanan Terpadu satu Pintu Provinsi Riau.

Hal tersebut, akan berdampak pada budaya organiasasi yang berada pada Dinas Penanaman Modal dan Pelayanan Terpadu satu Pintu Provinsi Riau yang dapat berpengaruh dengan komitmen DPMPTSP Provinsi Riau dalam menjalankan prinsip-prinsip pelayanan publik 'Cepat, Efisien, Responsif, Integritas, dan Akuntabel' dan sesuai dengan motto dan nilai organisasi yang dianut.

\section{KESIMPULAN}

Berdasarkan hail penelitian yang penulis lakukan terhadap Budaya Oragnisasi Pada Dinas Penanaman Modal dan Pelayanan terapdu satu Pintu Provinsi Riau, maka akan dipaparkan beberapa kesimpulan yang diperlukan. Budaya Organisasi pada Dinas Penanaman Modal dan Pelayanan Terpadu satu Pintu Provinsi Riau dapat dinilai dari 7 Indikator yaitu, Inovasi, Stabilitas, Orientasi pada Orang, Orientasi Pada hasil, bersikap Tenang, Perhatian pada hal Deatil, Orientasi pada kolaborasi Adapun kesimpulan ini dapat dikemukakan sebagai berikut:

a. Inovasi pada Dinas Penanama Modal dan Pelayanan Terpadu Satu Pintu Provinsi Riau sudah banyak mealukan inovasi yang dan banyak melalukan perubahan dilihat dari banyak nya penghargaan yang didapatkan oleh Dinas Penanaman Modal dan Pelayanan Terpadu Satu Pintu Provinsi Riau.

b. Stabilitas pada Dinas Penanamam Modal dan Pelayanan Terpadu Satu Pintu Provinsi Riau namun pada indicator ini belum sepenuhnya tercapai yaitu masih adanya visi dan misi yang belum terlaksanakan dengan baik.

c. Orientasi pada oaring di Dinas Penanaman Modal dan Pelayamam Terpadu satu Pintu Provinsi Riau namun pada Dinas Penanamam Modal dan Pelayanan Terpadu Satu Pintu Provinsi Riau pada indikator ini belum sepenuhnya tercapai dapat dilihat dari masih adanya kendala yaitu lamanya penerbitan izin pelayanan. 
d. Orientasi pada Hasil Dinas Penanamam Modal dan Pelayanan Terpadu Satu Pintu Provinsi Riau pada indicator ini belum sepenuhnya tercapai dapat lihat dari masi adanya pegawai yang telat datang kekantor.

e. Bersikap tenang pada Dinas Penanaman Modal dan Pelayanan Terpadu Satu Pintu Provinsi Riau pada indicator ini sudah diterapkan dengan baik dapat dilihat dari sikap pegawai dalam melaksanakan pelayanan yang sesuai dengan motto Dinas Penanamam Modal dan Pelayanan Terpadu Satu Pintu Provinsi Riau yaitu CERIA.

f. Perhatian pada Hal Detail Namun pada Dinas Penanamam Modal dan pelayanan Terpadu Satu Pintu Provinsi Riau sudah diterapkan dengan baik dapat dilihat dari disiplin pegawai dalam melaksanakan pelayanan.

g. Orientasi pada kolaborasi Namun pada Dinas Penanaman Modal dan Pelayanan terpadu satu Pintu Provinsi Riau sudah diterapkan dengan baik dapat dilihat dari komunikasi yang antar pegawai yang lebih megunakan system kekelurgaan.

\section{SARAN}

Adapun faktor penghambat dalam Budaya organisasi Dinas Penanamam Modal dan Pelayanan Terpadu satu Pintu Provinsi Riau yaitu Lamanya penerbitan izin yang dilakuakan pada Dinas Penanamam Modal dan Pelayanan Terpadu Satu Pintu Provinsi Riau dan Lemahnya pemberian sanksi Pada Dinas Penanamam Modal dan Pelayanan Terpadu Satu Pintu Provinsi Riau.Ada beberapa Saran dari penulis dalam penelitian ini, yaitu :

1. Hendaknya Pegawai Dinas Penanaman Modal dan Pelayanan Terpadu Satu Pintu Provinsi Riau dalam melaksanakan tugas nya mampu dengan menguasaai segala prosedur pelayanan yang telah ditetapkan agar tidak terjadinya keterlambatan dalam melakukan penerbitan perizinan.

2. Adanya pemberian reward kepada Pegawai agar pegawai yang mempunyai kinerja yang baik akan merasa diperhatikan dan dipersamakan dengan pegawai yang butuk kinerjanya. dan agar pegawai lebih semangat dalam melaksanaan pekerjaan. Hal ini akan mempengaruhi dalam pencapaian visi dan misi organisasi.

3. Pegawai Dinas Penanamam Modal dan pelayanan Terpadu Satu Pintu Provinsi Riau lebih menpererat tali persaudaraan antara seluruh pegawai dilingkungan Dinas Penanamam Modal dan Pelayanan Terpadu Satu Pintu Provinsi Riau untuk meningkatkan Team work dan pembagian pekerjaan secara professional kepada pegawai.

4. Bagi Pegawai Dinas Penanamam modal dan Pelayanan Terpadu Satu Pintu Provinsi Riau hendaknya lebih meperhatikan penerapan budaya organisasi yang pada lingkungan Dinas Penanamam Modal dan Pelayanan Terpadu Satu Pintu Provinsi Riau.

\section{DAFTAR PUSTAKA}

[1]. Badrudin. 2013. Dasar-Dasar Manajemen, ,Bandung: Alfabeta

[2]. Handoko T. Hani. 2012. Manajemen Sumber Daya Manusia, Bandung: Salemba Empat.

[3]. Kurniawan, Agung. 2011. Transformasi Pelayanan Publik. Yogyakarta: Pembaruan.

[4]. Kurniawan, Agung, 2010. Budaya Organisasi. Pt. Raja Grafindo Persada. Jakarta 
[5]. Nurmansyah.2016, Perilaku Organisasi, Pekanbaru: Unilak Pres.

[6]. Nawawi, Ismail., Budaya Organisasi Kepemimpinan dan kinerja, Jakarta: Pramedia Group. 2015

[7]. Rucky,2015, dasar-dasar management, gadjah mada management university pres,

[8]. Simamora, H, 2014 Menagemen sumber Daya manusia. Penerbit

[9]. Sugiyono. 2012. Metode Penelitian Administrasi. Bandung: CV. Alfabeta.

[10]. Syafie,H. Inu Kencana,2015, Budaya Organisasi, Bumi aksara, Jakarta

[11]. Melina,Ratnawati, Pengaruh Budaya Organisasi Terhadap Kinerja Pegawai, Jurnal Bisnis dan Ekonomi (JBE), September 2012, Hal. 170 - 187 Vol. 19, NoISSN:1412-3126

[12]. Rodiatul,Djudi, Yuniadi ,Pengaruh Budaya Organisasi Terhadap Kinerja Pegawai,

[13]. Subkhi, Ahmad dan Jauhari, Mohammad, 2013. Pengantar Teori Dan Perilaku Organisasi. Jakarta: Prestasi Pustaka

[14]. Wahyuni, Taufik, dan Reatnawati.(2016). Pengaruh Budaya Organisasi Terhadap Kinerja Organisasi dan Kepuasan Kerja sebagai variable Intervesting (studi empiris Pada pemerintah Bangkalis. Jurnal Manajement Vol.20 No.2: 189-206

[15]. Sumardi, Penelitain Analisis Pengaruh Budaya Organisasi dan Gaya Kepemimpinan Terhadap Kepuasan Kerja dan Kinerja Karyawan

[16]. Suryadi, H. Sholeh, et al. "Analisis Pengaruh Budaya Organisasi dan Komunikasi Organisasi Terhadap Kinerja Pegawai Pada Dinas Pendidikan Provinsi Jawa Barat." Jurnal Ilmu Administrasi" Akselerasi" 2.1 (2017): 121-148.

[17]. Torang, Syamsir,2014, Organisasi dan management,Alfabeta, Bandung

[18]. Website DPMPTSP Provinsi Riau

[19]. Wibowo, 2014. Manajemen Kinerja, Jakarta: Rajawali Press

[20]. Wibowo,2010.Budaya Organisai,Raja Grafindo Persada,JakartaYogyakarta

[21]. Chita,Susi,Dyah Lituhayu.2016. Jurnal Pengaruh Motivasi dan Budaya Organisasi Terhadap Kinerja Pegawai di Badan Penanaman Modal dan Pelayanan Terpadu Kabupaten Jepara,Semarang: Jurusan Administrasi Publik Fakultas Ilmu Sosial dan Politik Universitas Diponegoro. 